\title{
AN UNUSUAL CASE OF GRANULOMATOUS MASTITIS IN MALE PATIENT
}

Siddhi Patili ${ }^{1}$, Ashutosh Chitnis ${ }^{2}$, Rohit Kandalkar ${ }^{3}$, Pankaj Yadav ${ }^{4}$, Ishan Pranay ${ }^{5}$

\section{HOW TO CITE THIS ARTICLE:}

Siddhi Patil, Ashutosh Chitnis, Rohit Kandalkar, Pankaj Yadav, Ishan Pranay. "An Unusual Case of Granulomatous Mastitis in Male Patient". Journal of Evolution of Medical and Dental Sciences 2015; Vol. 4, Issue 60, July 27; Page: 10562-10564, DOI: 10.14260/jemds/2015/1523

ABSTRACT: Granulomatous mastitis is a very rare breast inflammatory disease of unknown origin that can clinically mimic carcinoma of breast.(1) It mainly affects young women of child bearing age, but has been reported in men and elderly women as well.(2) Here we report an unusual case of granulomatous mastitis diagnosed after breast biopsy. The patient is 65 years old man having swelling in right breast since a year. There was history of trauma a year back. There was no family history of breast carcinoma and patient had no significant personal history. Consequently, ultrasonography of right breast was done which revealed breast abscess.

INTRODUCTION: Granulomatous mastitis is a rare benign disease, first described by Kessler and Wolloch in 1972. The most common clinical presentation is a unilateral firm, discrete breast mass often associated with inflammation of surrounding skin, but bilateral involvement has been reported. Because clinically this lesion stimulates carcinoma, definitive diagnosis is made using histopathology/ as the clinical presentation and radiological imaging of idiopathic granulomatous mastitis can mimic two common breast diseases, mastitis with abscess and breast carcinoma, a tissue biopsy is required for histopathological diagnosis. The lesion is characterized histologically by primary lobulocentric granulomas which often contain neutrophils. Foci of necrosis may be present within granuloma, but the caseous necrosis is not seen. Other causes such as granulomatous inflammation such as infection, sarcoidosis, and reaction to foreign materials were excluded.(3)

CASE REPORT: Here we report a case of 65years old man with swelling of right breast since a year and history of trauma a year back. The patient was referred from outside to our Radiology department. Ultrasonography of right breast was done which revealed ill-defined heterogeneous predominantly hypoechoic collection seen with internal echoes measuring $2.4 \times 1.7 \times 1.7 \mathrm{~cm}$ (Approximately measuring 4cc) in areolar region (3'oclock position) with inflammation of adjacent breast parenchyma. This was diagnosed sonographically as breast abscess. Left breast was completely normal.

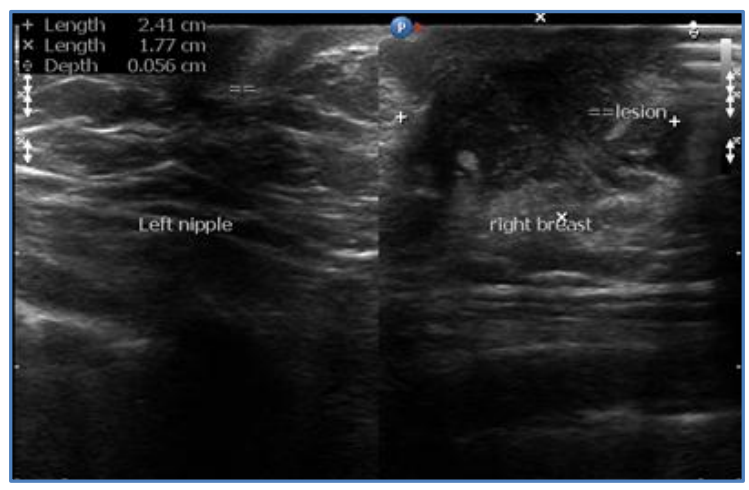

Hypoechoic Collection in Areolar Region with Surrounding Inflammation in Right Breast 


\section{CASE REPORT}

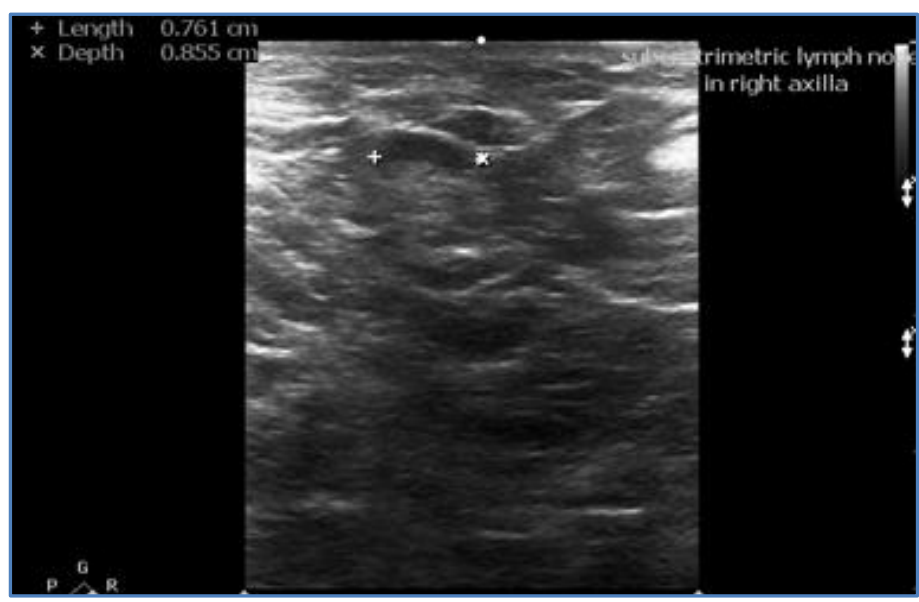

A Subcentrimetric Lymph Node in Right Axilla

On examination: A single, firm to hard, immobile, non-tender lump in right breast in areolar region at 3 o clock position measuring $2 \times 2 \mathrm{~cm}$ was noticed. Skin adjacent and overlying the swelling was reddish.

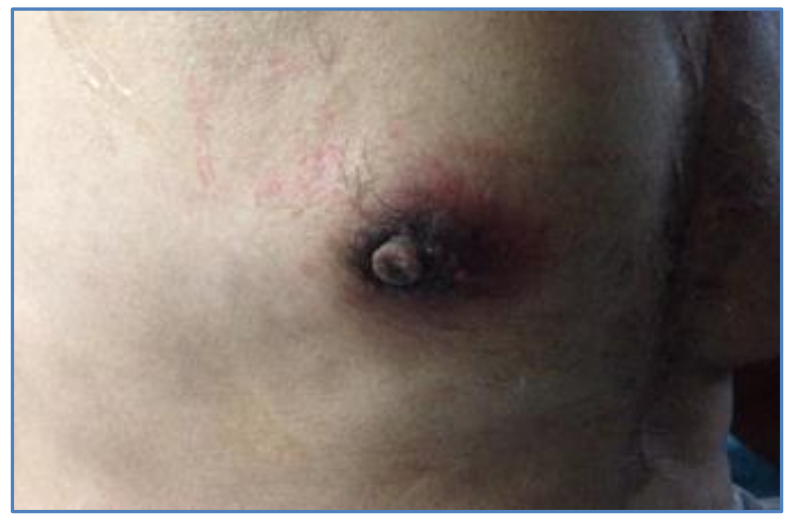

A proven diagnosis was given on histopathology which revealed well-formed epithelioid cell granulomas along with neutrophils, histocytes and lymphocytes against a necrotic background. Also seen were multiple foreign bodies and Langerhans type of giant cells.

DISCUSSION: The aetiology is still unclear. Kesser and Wolloch proposed as autoimmune pathogenesis.(4) Others include trauma, infection. Granulomatous mastitis within the breast may be secondary and represent a manifestation of systemic disease such as Wegener's Granulomatosis, sarcoidosis, diabetes mellitus and connective tissue disorders. Mammography features are variable, ranging from normal findings in patients with dense breast to masses with benign/ malignant features and focal asymmetric density, most frequently described abnormality. Reactive lymphadenopathy is found to be reported in $15 \%$ of cases.(2)

The recommended treatment of granulomatous mastitis is complete resection or corticosteroid therapy.(5) Resection is complicated by fistulae, abscess formation/chronic suppuration. Recurrence is common problem and without surgical management, patient may undergo a chronic progressive clinical course. Long term follow-up is essential.(6) 


\section{BIBLIOGRAPHY:}

1. Joseph M. Sabaté, MD, Monste Clotet MD, Antonio Gomez, MD, Pilar de Las Heras, MD, Sofia Torrubia, MD, Teresa Salinas MD RSNA education exhibits Radiologic Evaluation of Uncommon Inflammatory and Reactive Breast Disorders. March- April 2005, Volume 25, Issue 2.

2. Anmol Gupta Bansal, MD; Lily Zou, MD; Leonard B. Resnikoff, MD; Fatima Sheikh, BS; Julie M. DiGioia, MD; and Henry Resnikoff, EMT Idiopathic granulomatous mastitis masquerading as a postbiopsy abscess Radiology Case Reports. (Online) 2013; 8; 773.

3. Fariba Binesh, Saied Kargar, Shokouh Toghipour Zahir, Nasim Behniafard, Hossein Navabi, Saied Arefanian: Idiopathic granulomatous mastitis, a clinicopathologic review of 22 cases. Clinical and Experimental pathology, Binesh et al. J Clin Exp Pathol 2014, 4:2.

4. Ragu Vinayagam, Julie Cox and Lesley Webb Granulomatous mastitis: a spectrum of disease NCBI v 4 (4) sept 2009. Breast care (basel) 251-254. Published online 2009 august 3.

5. Shigeru Imoto, Tomoki Kitaya, Testsuro Kodama, Takahiro Hasebe, Kiyoshi Mukai. Idiopathic Granulomatous Mastitis: Case Report and Review of the Literature Japanese Journal of Clinical Oncology, volume 27, issue 4.

6. Farrah M Yau MD, Sheina A Macadam MD FRCSC, Urve Kuusk MD, Michael Nimmo MD FRCPC, Nancy Van Lacken MD FRCSC The Surgical Management of Granulomatous mastitis.

\section{AUTHORS:}

1. Siddhi Patil

2. Ashutosh Chitnis

3. Rohit Kandalkar

4. Pankaj Yadav

5. Ishan Pranay

\section{PARTICULARS OF CONTRIBUTORS:}

1. $2^{\text {nd }}$ Year Junior Resident, Department of Radio-Diagnosis, MGM Medical College \& Hospital, Kamothe.

2. Associate Professor, Department of Radio-Diagnosis, MGM Medical College \& Hospital, Kamothe.

3. $2^{\text {nd }}$ Year Junior Resident, Department of Radio-Diagnosis, MGM Medical College \& Hospital, Kamothe.

FINANCIAL OR OTHER COMPETING INTERESTS: None
4. $2^{\text {nd }}$ Year Junior Resident, Department of Radio-Diagnosis, MGM Medical College \& Hospital, Kamothe.

5. $2^{\text {nd }}$ Year Junior Resident, Department of Radio-Diagnosis, MGM Medical College \& Hospital, Kamothe.

\section{NAME ADDRESS EMAIL ID OF THE CORRESPONDING AUTHOR:}

Dr. Siddhi Patil,

81, Kalpataru Royale,

Road No. 29, Plot No. 110,

Near Sion Telephone Exchange,

Sion Mumbai-400022.

E-mail: drsiddhip2014@gmail.com

Date of Submission: 04/07/2015.

Date of Peer Review: 06/07/2015.

Date of Acceptance: 21/07/2015.

Date of Publishing: 27/07/2015. 